\title{
THE IMPACT OF ISLAMIC BANK'S CORPORATE SOCIAL RESPONSIBILITY AND TOTAL FINANCING ON THE ECONOMIC GROWTH OF JORDAN
}

\author{
DOI: 10.17261/Pressacademia.2021.1502 \\ PAP- V.14-2021(28)-p.119-120
}

\section{Elias Abu Al-Haija}

Emirates College of Technology, Accounting \& Finance Department, Abu Dhabi, UAE. elias.haija@ect.ac.ae, ORCID: 0000-0002-1308-4421

\section{To cite this document}

Elias Abu AL-Haija, (2021). The impact of Islamic bank's corporate social responsibility and total financing on the economic growth of Jordan. PressAcademia Procedia (PAP), 14, 119-120.

Permanent link to this document: http://doi.org/10.17261/Pressacademia.2021.1502

Copyright: Published by PressAcademia and limited licensed re-use rights only.

\begin{abstract}
Purpose- The purpose of this study is to investigate the corporate social responsibility (CSR) in Islamic banks of Jordan. The objective was to investigate whether their CSR activities are having an impact on the economy. It was also important to measure the impact of total finances provided by Islamic banks on the economic sector of Jordan.

Methodology- The study employs Gross Domestic Product (GDP) as a dependent variable to measure impact of CSR and total financing. Secondary data was used from bank's annual reports for data analysis for the period of 2014-2019. Various hypotheses were tested through regression analysis to fulfill the research objectives. The approach used in this study was analytical.

Findings- The analysis reveals that a positive relationship between CSR and GDP. Results showed that CSR unique to Islamic banks especially Qard Al Hasan has a significantly positive impact on the GDP. Whereas donations did not have any impact on the GDP. Moreover, total finances given out by Islamic banks had a positive impact on the country's GDP.

Conclusion- based upon the analysis \& Findings it may be concluded that CSR carried out by Islamic banks effects the economic growth of a country. It was noticed that CSR unique to Islamic Banks (i.e., Qard al Hasan) showed a significant positive impact on the GDP. A units' increase in Qard al Hasan consecutively led to the increase of GDP by 117.0206 units. The research additionally analyzed the impact of total financing -carried out by Islamic banking sector- on economic growth. It was found that although JIB had the highest number of total finances, IIAB had the highest impact on the economy. This proved that a high amount of bank financing does not necessarily imply a higher impact on the economy. Other factors such as the banks' diversity of finances, strategies, motivations, and other internal organizational factors might influence this impact.
\end{abstract}

Keywords: Islamic banking, Sharia, corporate social responsibility, gross domestic product, Qard Al Hasan JEL Codes: G10, G20

\section{REFERENCES}

Al- Daaya, Y. (2017). Corporate Social Responsibility Scenario in Jordan: Transformation Context. International Journal of Engineering And Management Sciences, 2(3), 1-10.

AL-Haija, Elias; Kolsi, Mohamed, (2021). “Corporate Social Responsibility in Islamic Banks: To which Extent does Abu Dhabi Islamic Bank Comply with the Global Reporting Initiative Standards?", Journal of Islamic Accounting and Business Research, 12(8), $1200-1223$.

Al Qadi, S. (2012). Social Responsibility of Islamic Banks (Jordan Case). British Journal Of Humanities And Social Sciences, 6(1), $12-20$.

Al Zyoud, I. (2017). Impact of Corporate Social Responsibility Implementation in Jordanian Public Shareholding Companies on Sustainable Development. Asian Social Science, 13(2), 94-106.

Barakat, A., Samhan, H., \& Omar, A. (2014). Accounting Social Responsibility In Islamic Banks. International Journal Of Economics, Commerce And Management, 2(10), 1-15. 
Blasi, S., Caporin, M., \& Fontini, F. (2018). A Multidimensional Analysis of the Relationship Between Corporate Social Responsibility and Firms' Economic Performance. Ecological Economics, 147(1), 218-229.

Boulouta, I., \& Pitelis, C. (2013). Who Needs CSR? The Impact of Corporate Social Responsibility on National Competitiveness. Journal Of Business Ethics, 119(3), 349-364.

Caporale, G., Rault, C., Sova, R., \& Sova, A. (2009). Financial Development and Economic Growth: Evidence from Ten New EU Members. Deutsches Institut Für Wirtschaftsforschung Discussion Papers, 940.

Durham, J. (2003). Foreign Portfolio Investment, Foreign Bank Lending, and Economic Growth. SSRN Electronic Journal.

Echchabi, A., Abd.Aziz, H., \& Idriss, U. (2016). Does Sukuk Financing Promote Economic Growth An Emphasis On The Major Issuing Countries. Turkish Journal Of Islamic Economics, 3(2), 63-63.

El-Galfy, A., \& Khiyar, K. (2012). Islamic Banking and Economic Growth: A Review. The Journal Of Applied Business Research, $28(5)$, $943-955$.

Elmawazini, K., Khiyar, K., \& Aydilek, A. (2020). Types of banking institutions and economic growth. International Journal Of Islamic And Middle Eastern Finance And Management, 13(4), 553-578.

Farook, S., Hassan, M., \& Lanis, R. (2011). Determinants of corporate social responsibility disclosure: the case of Islamic banks. Journal Of Islamic Accounting And Business Research, 2(2), 114-141.

Gudarzi Farahani, Y., \& Dastan, M. (2013). Analysis of Islamic banks' financing and economic growth: a panel cointegration approach. International Journal Of Islamic And Middle Eastern Finance And Management, 6(2), 156-172.

Hachicha, N., \& Amar, A. (2015). Does Islamic bank financing contribute to economic growth? The Malaysian case. International Journal Of Islamic And Middle Eastern Finance And Management, 8(3), 349-368.

Haddad, H. (2017). Corporate Social Responsibility (CSR) Practices Of Islamic Banks in Jordan A Case Study on Jordan Islamic Bank. The Annals Of The University Of Oradea, Economic Science, 1, 609-619.

Ibrahim, A., \& Hanefah, M. (2016). Board diversity and corporate social responsibility in Jordan. Journal Of Financial Reporting And Accounting, 4(2), 279-298.

Iqbal, Z., \& Shafiq, B. (2015). Islamic Finance and The Role Of Qard-Al-Hassan (Benevolent Loans) In Enhancing Inclusion: A Case Study Of Akhuwat. ACRN Oxford Journal Of Finance And Risk Perspectives Special Issue Of Social And Sustainable Finance, 4(4), $25-27$.

Selim, M. (2018). The effectiveness of Qard-al-Hasan (interest free loan) as a tool of monetary policy. International Journal Of Is/amic And Middle Eastern Finance And Management, 12(1).

Selim, M., \& Hassan, M. (2019). Interest-free monetary policy and its impact on inflation and unemployment rates. ISRA International Journal Of Islamic Finance, 11(1), 46-61.

Škare, M., \& Golja, T. (2014). The impact of government CSR supporting policies on economic growth. Journal Of Policy Modeling, 36(3), 562577.

Tohirin, A., \& Ismail, A. (2011). MMM in the finance-growth nexus. Investment Management And Financial Innovations, 8(3), $130-147$.

Widiyanto, Mutamimah, \& Hendar. (2011). Effectiveness of Qard Al Hasan financing as a Poverty Alleviation Model. Economic Journal Of Emerging Markets, 3(1).

Zarrouk, H., Al-Haija, A., \& Ghak, T. (2017). Financial development, Islamic finance and economic growth: evidence of the UAE. Journal Of Islamic Accounting And Business Research, 8(1), 2-22. 